\title{
The Antidiabetic Activity of Cocor Bebek Leaves' (Kalanchoe pinnata Lam.Pers.) Ethanolic Extract from Various Areas
}

\author{
Indah Dwiatmi Dewiyanti $^{1 *}$, Euis Filailla ${ }^{1}$, Megawati $^{1}$, Tri Yuliani ${ }^{1}$
}

${ }^{1}$ Research Centre for Chemistry, Indonesian Institute of Sciences

\begin{abstract}
The anti-diabetic activity of Cocor Bebek leaves' (Kalanchoe pinnata Lam.Pers.) ethanolic extract from Bogor city, Kabupaten Bogor, and Tangerang Selatan (south of Tangerang) city has been studied. The study was conducted in vitro using $\alpha$-glucosidase inhibitor method. The results of the study showed that the $\mathrm{IC}_{50}$ of the extract from Bogor city, Kabupaten Bogor, and Tangerang Selatan city is $40.94 \mathrm{ppm}$, $33.58 \mathrm{ppm}$ and $16.12 \mathrm{ppm}$, respectively. Meanwhile, the $\mathrm{IC}_{50}$ of quercetin which has antidiabetic activity is $10.22 \mathrm{ppm}$. The results showed that Cocor Bebek leaves' (Kalanchoe pinnata Lam.Pers.) ethanolic extract had anti-diabetic activity with $\mathrm{IC}_{50}$ less than $100 \mathrm{ppm}$. However, the activity is lesser than quercetin.
\end{abstract}

Keywords: Kalanchoe pinnata Lam.Pers., antidiabetic activity, a glucosidase inbibitor

\section{BACKGROUND}

Cocor Bebek (Kalanchoe pinnata Lam.Pers.), belongs to sukulen plants which has thick and watery leaves [1,2]. The plant lives in tropical area. In Vietnam it is called Thuoc bong, cay song don, truong sinh, diep sinh can, da bat tur, or tau pua sung; while in the Philippines it is called Katakataka, siempre viva, abisrana, aritana, or karitana [3, 4]. In Indonesia the plant is more popular as an ornamental plant than medicinal one [2]. K. pinnata contains alkaloid, triterpene, glycoside, flavonoid, steroid and lipid. In Guatemala and India, the plant is used to treat diabetes [5].

Diabetes mellitus is a chronic metabolic disorder involving the metabolism of carbohydrates, fats and proteins, in which the disorder is characterized by the increase in blood sugar (hyperglycemia). There are two types of diabetes mellitus, namely, insulin-dependent diabetes mellitus/IDDM (type 1) and non-insulin dependent diabetes mellitus/NIDDM (type 2). Treatment for the type 2 is by regulating blood sugar levels by means of using hypoglycemic, $\alpha$ glucosidase inhibitor and a diet that limits the use of sugar $[6,7]$.

Glucosidase is an enzyme that is needed in the process of carbohydrate metabolism. It is

\footnotetext{
* Corresponding address:

Indah Dwiatmi Dewiyanti

Research Centre for Chemistry,

Indonesian Institute of Sciences,

Kompleks Puspiptek, Serpong-Indonesia 15412

Email: anik_baik@yahoo.com
}

located on the banks of the surface of intestinal cells and is a key enzyme in the metabolism. Moreover, it is needed in the process of glycoprotein and glycolipid formation [8]. The enzyme breaks down carbohydrates into glucose in the human intestine [9]. Compounds that can inhibit the activity indicate that the compound has a possibility as anti-diabetes by lowering blood sugar levels [10].

Because of the use of $K$. pinnata as antidiabetic treatment, an evidence obtained from in vitro testing using $\alpha$-glucosidase inhibitor methods is needed. The method uses spectrophotometry by reacting substrate $\mathrm{p}$ nitrophenyl $\alpha$-D-glucopiranoside, the enzyme $\alpha$ glucosidase and the ethanol leaves extract [8]. Considering that the pharmacology activity of natural products are influenced by environmental factor where they live, Cocor Bebek leaves were taken from different areas in order to compare its activity.

\section{MATERIALS AND METHODS}

\section{Ethanol extract of K.pinnata Preparation}

Fresh $K$. pinnata leaves were obtained from Bogor city (BALITRO), Kabupaten Bogor (Pabuaran), and Tangerang Selatan city (PUPIPTEK area-Serpong). The species determination was done in Research Center for Biology_LIPI, Cibinong. The leaves were dried by using oven at $50^{\circ} \mathrm{C}$, then blended and 
macerated by using ethanol $70 \%$ for $3 \times 24$ hours. After that, They were filtered and evaporated by using a rotary evaporator, then dried by using water bath at $50^{\circ} \mathrm{C}$ until they were viscous. $1 \%, 0,5 \%$ and $0,25 \%$ (b/v) solution of $K$. pinnata extract were, then, prepared.

\section{$\alpha$-Glucosidase Inhibitory Activity of K. pinnata's Extract}

$\alpha$-glucosidase activity was determined by using Lee \& Lee's (2001) method, that is, Spectrophotometry method at $400 \mathrm{~nm}$ wave length. $\alpha$-glucosidase, bovine serum albumin (Wako Pure Chemical Industries, Ltd.), pnitrophenyl $\alpha$-D-glucopiranoside (Wako Pure Chemical Industries Ltd.), Bufer fosfat $\mathrm{pH} 7$, DMSO, $\mathrm{Na}_{2} \mathrm{CO}_{3}$, and Quercetin were used as the standard. $\alpha$-glucosidase enzyme was diluted $1 / 10$ times before assay. $200 \mathrm{mg}$ bovine serum albumin and $1.0 \mathrm{mg} \alpha$-glucosidase were diluted in buffer phosphat $\mathrm{pH}$ (7.0). The mixing solution contains $250 \mu \mathrm{l}$ solution of $20 \mathrm{mM}$ p- nitrophenyl $\alpha$-D-glucopiranoside, $495 \mu$ l buffer phosphat $(\mathrm{pH}$ 7.0), and $5 \mu \mathrm{l}$ sample. Then, it was pre-incubated at $37^{\circ} \mathrm{C}$ for a while. Reaction was started by adding $250 \mu \mathrm{l} \alpha$-glucosidase, then incubated it at $37^{\circ} \mathrm{C}$ for a while. The reaction was stopped by adding $1000 \mu \mathrm{l} \mathrm{Na}{ }_{2} \mathrm{CO}_{3}$ solution. The amount of p-nitrofenol obtained was measured at $400 \mathrm{~nm}$ wave length. The percentage of the inhibitory activity was counted by using this formula:

$$
\text { Inhibitory activity }(\%)=\frac{(\mathrm{C}-\mathrm{S})}{\mathrm{C}} \times 100
$$

where $\mathrm{C}=$ absorbance of enzyme activity without inhibitor (absorbance of DMSO), and S $=$ absorbance of enzyme activity with sample examined.

\section{RESULT AND DISCUSSION}

$\mathrm{IC}_{50}(\mathrm{ppm})$ were counted from the regression equation (concentration vs inhibition percentage). $1 \%$ concentration of sample in reaction mixture is $25 \mathrm{ppm}$. The graphs are shown in Figure 1 until 4.

Tabel 1. IC50 ethanolic extract of K. pinnata (Lam.Pers.)

\begin{tabular}{|l|c|}
\hline Sample & IC50 \\
\hline Quercetin & 10.22 \\
\hline CB EtOH Bogor City & 40.94 \\
\hline CB EtOH Kabupaten Bogor & 33.58 \\
\hline CB EtOH Tangerang Selatan City & 16.12 \\
\hline
\end{tabular}

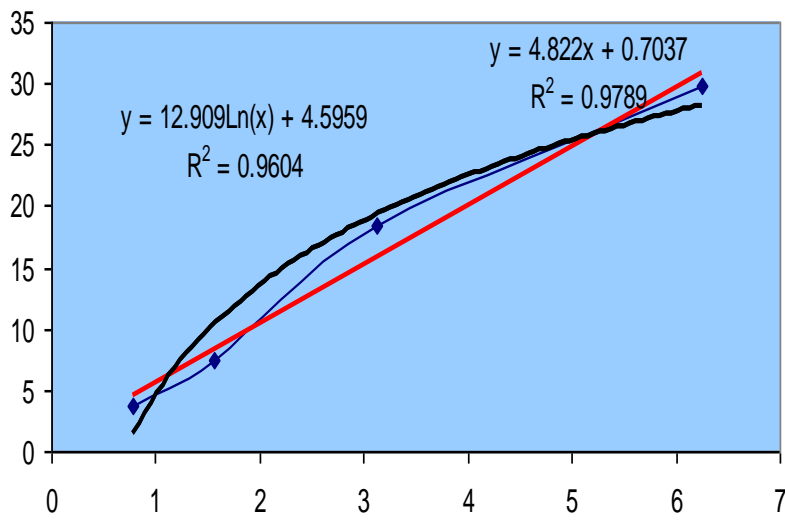

Figure 1. Regression equation of quercetin as standard

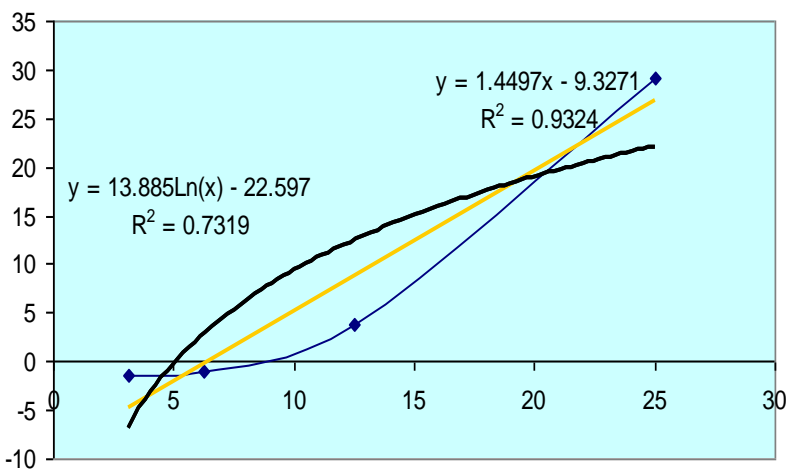

Figure 2. Regression equation of Cocor Bebek's ethanolic extract from Bogor City

Ethanol was used as solvent in order to obtain less polar compound until the polar compound reached maximum. The ethanol can extract alkaloid, sterol, saponin, flavonoid Anthraquinone and glicoside compound from plants. Quercetin, a flavonoid compound which has antioxidant property, was used as the standard because of its anti-diabetic activity as shown by the research carried by Vessal et al. (2003) in which they used streptozocin induced diabetic rat [11].

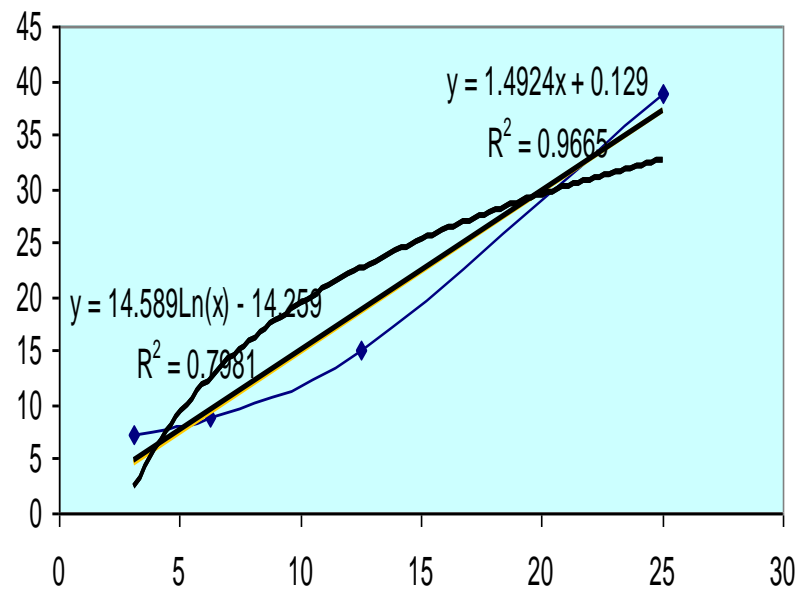

Figure 3. Regression equation of Cocor Bebek's ethanolic extract from Kabupaten Bogor 


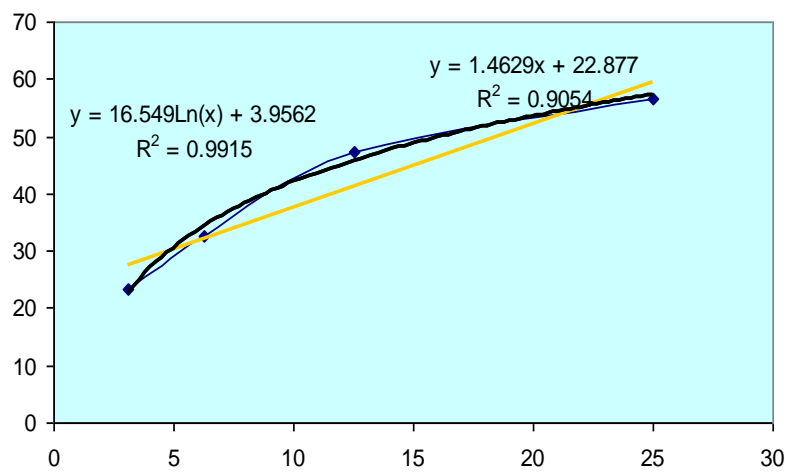

Figure 4. Regression equation of Cocor Bebek's ethanolic extract from Tangerang Selatan city

The results of this study showed that $\mathrm{IC}_{50}$ of the extract from Bogor city, Kabupaten Bogor, and Tangerang Selatan city is $40.94 \mathrm{ppm}, 33.58$ ppm, and $16.12 \mathrm{ppm}$, respectively. Meanwhile, quersetin, which has antidiabetic activity, has $\mathrm{IC}_{50} 10.22 \mathrm{ppm}$. This study shows that the antidiabetic activity of $K$. pinnata ethanolic extract varies. Its habitat and the sunlight can influence flavonoid compound in the plant such as quercetin [12]. The sunlight can improve flavonoid constituent in the plant as a result of adaptation because of the near wave length effect of the sunlight $[13,14]$. Temperature and water supply at certain season can also influence flavonoid constituent in leaves $[15,16]$.

\section{CONCLUSION}

The result of this study shows that $K$. pinnata's ethanolic extract has anti-diabetic properties and the activity is influenced by the habitat of the plant. The drier the climate, the stronger the activity will be.

\section{ACKNOWLEDGEMENTS}

The authors would like to thank "Program Insentif Peningkatan Kemampuan Peneliti \& Perekayasa (2011)" held by LIPI for supporting this study.

\section{REFERENCES}

1. Materia Medika Indonesia Vol. 5 (1989) page 290 Jakarta: Departemen Kesehatan Republik Indonesia.

2. P.T. EISAI Indonesia (1995) Medicinal Herb Index in Indonesia (second edition), page 219.

3. De Padua LS, Lugod GC, and Pancho JV (1983) Handbook on Philippine Medicinal Plants (Vol.2). Technical Bulletin. University of The Philippines at Los Banos. 3(3). page 32.
4. Medicinal Plants in Hanoi, Vietnam (1990) WHO Regional Publications Western series No. 3. Institute of Materia Medica Hanoi, page 35.

5. http://www.rain-tree.com/coirama.htm.

6. Williamson EM, Okpako DT, Evans FJ (1998) Pharmacological Methods in Phytotherapy Research, Selection, Preparation and Pharmacological Evaluation of Plant Material, Jhon Wiley \& Sons, Chichester. New York. Brisbane. Toronto. Singapore, Vol I, page 93106.

7. Dalimatra S (1998) Ramuan Tradisional Untuk. Pengobatan Diabetes Mellitus. Swadaya.

8. Lee DS and Lee SH (2001) Genistein, a Soyisoflavone, is a Poten $\alpha$ - Glucosidase Inhibitor; FEBS Letters. 501: 84-86

9. http://www.diabetes-drug.net. Information on Hypoglycemics, Starch blockers, Insulin.

10. Yoshikawa M, et al (2001) Search for Antiobesitic and Antidiabetogenic Principles from Salacia species. Conference Proceeding 2A03. Kyoto Pharmaceutical University and Morishita Jintan Co. Ltd.

11. Vessal M, Hemmati M, Vasei M (2003) Antidiabetic Effects of Quercetin in Streptozocin-induced Diabetic Rats. Comp Biochem Physiol C Toxicol Pharmacol. 135C (3): 357-64.

12. Hagen F, Borge GIA, Bengtsson GB, Bilger W, Berge A, Haffner K, Solhaug KA (2007) Phenolic Content Sand Other Health and Sensory Related Properties of Apple Fruit (Malus domestica Borkh., cv. Aroma): Effect of Post Harvest UVB Irradiation. Post-harvest Biological Technology. 45: 1-10.

13. Tattini M, Galardi C, Pinelli P,Massai R, Remorini D, Agati G (2004) Differential Accumulation of Flavonoids and Hydroxycinnamates in Leaves of Ligustrum Vulgare under Excess Light and Drought Stress. New Phytologist. 163: 547-561.

14. Tattini M, Gravano E, Pineli P, Mulinacci N, Romani A (2000) Flavonoids Accumulate in Leaves and Glandulart Richomes of Phillyrea Latifolia Exposed to Excess Solar Radiation. New Phytologist. 148: 69-77.

15. Yao LH, Caffin N, D’Arcy B, Jiang YM, Shi J, Singanusong R, Liu X, Datta N, Kakuda Y, Xu $Y$ (2005) Seasonal Variations of Phenolic Compounds in Australia-grown Tea (Camellia Sinensis). Journal Agriculture Food Chemistry. 53: 6477-6483.

16. Alonso-Amelot ME, Oliverosastidas A, Calcagno-Pisarelli MP (2007) Phenolics and Condensed Tannins of High Altitude Pteridium Arachnoideum in relation to Sunlight Exposure, Elevation, and Rain Regime. Biochemical Systematic Ecology. 35:1-10. 